\title{
Sympathetic neurons and chromaffin cells share a common progenitor in the neural crest in vivo
}

\author{
Stella Shtukmaster ${ }^{1 \dagger}$, Marie Catherine Schier ${ }^{2 \dagger}$, Katrin Huber ${ }^{1}$, Shlomo Krispin ${ }^{3}$, Chaya Kalcheim ${ }^{3 *}$ \\ and Klaus Unsicker ${ }^{1 *}$
}

\begin{abstract}
Background: The neural crest (NC) is a transient embryonic structure unique to vertebrates, which generates peripheral sensory and autonomic neurons, glia, neuroendocrine chromaffin and thyroid C-cells, melanocytes, and mesenchymal derivatives such as parts of the skull, heart, and meninges. The sympathoadrenal (SA) cell lineage is one major sub-lineage of the NC that gives rise to sympathetic neurons, chromaffin cells, and the intermediate small intensely fluorescent (SIF) cells. A key question is when during NC ontogeny do multipotent progenitors segregate into the different NC-derived lineages. Recent evidence suggested that sympathetic, sensory, and melanocyte progenitors delaminate from the thoracic neural tube (NT) in successive, largely non-overlapping waves and that at least certain NC progenitors are already fate-restricted within the NT. Whether sympathetic neurons and chromaffin cells, suggested by cell culture studies to share a common progenitor, are also fate segregated in ovo prior to emigration, is not known.

Results: We have conducted single cell electroporations of a GFP-encoding plasmid into the dorsal midline of E2 chick NTs at the adrenomedullary level of the NC. Analysis of their derivatives, performed at E6, revealed that in most cases, labelled progeny was detected in both sympathetic ganglia and adrenal glands, where cells co-expressed characteristic marker combinations.
\end{abstract}

Conclusions: Our results show that sympathetic neurons and adrenal chromaffin cells share a common progenitor in the NT. Together with previous findings we suggest that phenotypic diversification of these sublineages is likely to occur after delamination from the NT and prior to target encounter.

Keywords: Chicken embryo, Chromaffin cells, Neural crest, Single cell electroporation, Sympathetic neurons, Sympathoadrenal progenitors

\section{Background}

The neural crest $(\mathrm{NC})$ is a transient structure in developing vertebrate embryos that arises at the interface between the epidermal and neural ectoderm. Upon neural tube (NT) formation, NC cells delaminate from its dorsal aspect and undergo an epithelial-to-mesenchymal transition followed by migration to their target locations. $\mathrm{NC}$ cells give rise to many different cell types, including neurons and glia of the autonomic and sensory nervous systems, neuroendocrine chromaffin cells in the adrenal medulla and other locations,

\footnotetext{
*Correspondence: ku39@anat.uni-freiburg.de; kalcheim@cc.huji.ac.il

${ }^{\dagger}$ Equal contributors

${ }^{3}$ Department of Medical Neurobiology, IMRIC and ELSC-Hebrew University of Jerusalem, Hadassah Medical School, POB 12272, Jerusalem 9112102, Israel 'Department of Molecular Embryology, Institute of Anatomy and Cell Biology University of Freiburg, Albertstr. 17, Freiburg D-79104, Germany

Full list of author information is available at the end of the article
}

thyroid $\mathrm{C}$ cells, melanocytes, and selected populations of mesenchymal cells [1]. The sympathoadrenal (SA) cell lineage is a major sub-lineage of the NC that gives rise to sympathetic neurons, intra- and extra-adrenal chromaffin cells, and the small intensely fluorescent (SIF) cells, which are intermediate between sympathetic neurons and chromaffin cells [2-5]. SA derivatives share several features, including the ability to synthesize, store, and release catecholamines, but also exhibit traits specific for each cell type, such as axons, dendrites, and neurofilaments, which are only found in sympathetic neurons but not chromaffin cells.

After delaminating from the NT, the earliest emigrating $\mathrm{NC}$ cells migrate ventrally to the area of the dorsal aorta [6-8]. Here, they acquire catecholaminergic features, instructed by bone morphogenetic proteins $2 / 4 / 7$, which are secreted by cells of the wall of the dorsal aorta $[9,10]$.

\section{Biomed Central}


Furthermore, a series of interacting transcription factors including MASH-1, Phox2a, Phox2b, dHand, Gata2/3, and Insm1, were found to be essential for the generation of the SA catecholaminergic phenotype [11-19]; for reviews see $[2-6,20,21]$.

Cell culture studies using isolated SA progenitor cells from embryonic and early postnatal sympathetic ganglia and adrenal gland have suggested that glucocorticoids play a crucial role in the diversification of SA cells into sympathetic neurons and chromaffin cells [22-24]; for reviews see $[2,5,6,25]$, by suppressing a neuronal differentiation programme in SA cells destined to become chromaffin cells. However, analysis of mice deficient for the glucocorticoid receptor [26] or lacking an adrenal cortex [27] revealed that chromaffin cell differentiation was largely unimpaired suggesting that cues unrelated to glucocorticoid receptor signalling and the adrenal cortex triggered the chromaffin phenotype. This notion was corroborated and extended by studies showing that chick SA progenitors are already heterogeneous in terms of neurofilament-M (NF-M) expression prior to populating the adrenal gland and sympathetic ganglia [28] with presumptive neuronal cells co-expressing tyrosine hydroxylase (TH) and NF-M, and presumptive neuroendocrine cells being TH-positive and NF-M-negative. This indicated that specification of the respective phenotypes occurred either during migration or even prior to migration at the level of the NT.

A recent study by Krispin et al. [7,29] showed that in the trunk NT of avian embryos, precursors for sympathetic ganglia, Schwann cells, sensory dorsal root ganglionic neurons, and melanocytes leave the NT in successive, largely non-overlapping waves, some being already distinct while still residing in the NT. Although adrenal chromaffin cells were not addressed in this study, the results raised the possibility that sympathetic neurons and chromaffin cells might also already be distinct at the level of the NT. We therefore conducted single cell electroporations (EPs) of green fluorescent protein (GFP)-DNA into pre-migratory NC cells at the level of somites 18-24 ("adrenomedullary level"), where both chromaffin cells and sympathetic neurons arise [30]. The timing and location of EPs was directed to label the earliest progenitors that undergo delamination, previously shown to generate the sympathetic lineage $[7,29]$, and the progeny of labelled cells was then analysed at E6 following homing to their target areas. Our results indicate that in more than $80 \%$ of the cases the progeny of a single labelled cell ends up in both sympathetic ganglia and adrenal gland, being mostly NF-M-negative in the adrenal gland and NF-M-positive in sympathetic ganglia. This suggests that chromaffin cells and sympathetic neurons share a common progenitor in the NT and that diversification of the phenotypes occurs during migration or assembly in primary sympathetic ganglia at the dorsal aorta.

\section{Results and discussion}

Transfection of GFP-encoding DNA into single dorsal NT progenitors

Stereomicroscopic and histological analyses were performed $3.5 \mathrm{~h}$ following focal EP of the dorsal NT to examine the extent of single cell labelling upon initial GFP protein expression. Figure 1A schematically reveals the position of electrodes, injection site of GFP-DNA, and a single labelled cell in the dorsal NT. A single GFP+ cell at $3.5 \mathrm{~h}$ is shown by live-epi-fluorescence imaging (Figure 1B). By $24 \mathrm{~h}$ the cell had migrated out from the NT and generated a cluster of three cells (Figure 1C). Further confirmation of clonal transfection was obtained by confocal analysis (Figure 1D-D"'”). A summary of evaluated cases (Figure 1E) reveals that in 49 out of 69 cases showing labelled cells, only one GFP+ neuroepithelial cell (71\%) was detected at the NT level. In 19 cases (27.5\%) two cells were detected, and in one more case three cells were visible. Notably, the number of embryos showing labelled cells was approximately $12 \%$ of total electroporations performed; this low efficiency is in further support of the clonal nature of transfections.

\section{Distribution of the progeny of single NC progenitors following target organ colonization}

Electroporated embryos that showed a single labelled progenitor at $3.5 \mathrm{~h}$ post-EP were further incubated till E6 when adrenal gland and sympathetic ganglia were established and the progeny of electroporated cells had reached these organs. Embryos were then fixed, paraffin embedded and stained with GFP and TH antibodies. Figure 2 shows $\mathrm{GFP}+/ \mathrm{TH}+$ cells in a sympathetic ganglion (Figure 2A,B) and adrenal gland (Figure 2C,D), respectively. As summarized in Figure 2E in 24 out of 29 cases of the single-cell EPs we detected GFP+/TH+ cells in both locations, i.e., adrenal gland and sympathetic ganglia $(P=0.0004)$. In two cases $\mathrm{GFP}+/ \mathrm{TH}+$ cells were found within the adrenal gland only, and in another three cases in sympathetic ganglia only. The number of GFP-positive cells in each tissue varied from 1 to 18 cells in sympathetic ganglia, and 2 to 12 in adrenal glands, respectively (Table 1 ). Together, the number of cells in clones within sympathetic ganglia compared to adrenal glands was not statistically different $(P=0.5)$. Notably, in the 29 cases presented in which labelled progeny were detected in SA derivatives no additional NC derivatives were found to contain labelled cells. This confirms the existence of early fate restrictions as initially described by Krispin et al. [7,29] and more specifically, it further supports the notion that SA progenitors are segregated from the other neural derivatives of the NC.

In mammalian and avian sympathetic ganglia, neurons are not the exclusive type of cell found within the ganglion. In chick, sympathetic ganglia harbour about 


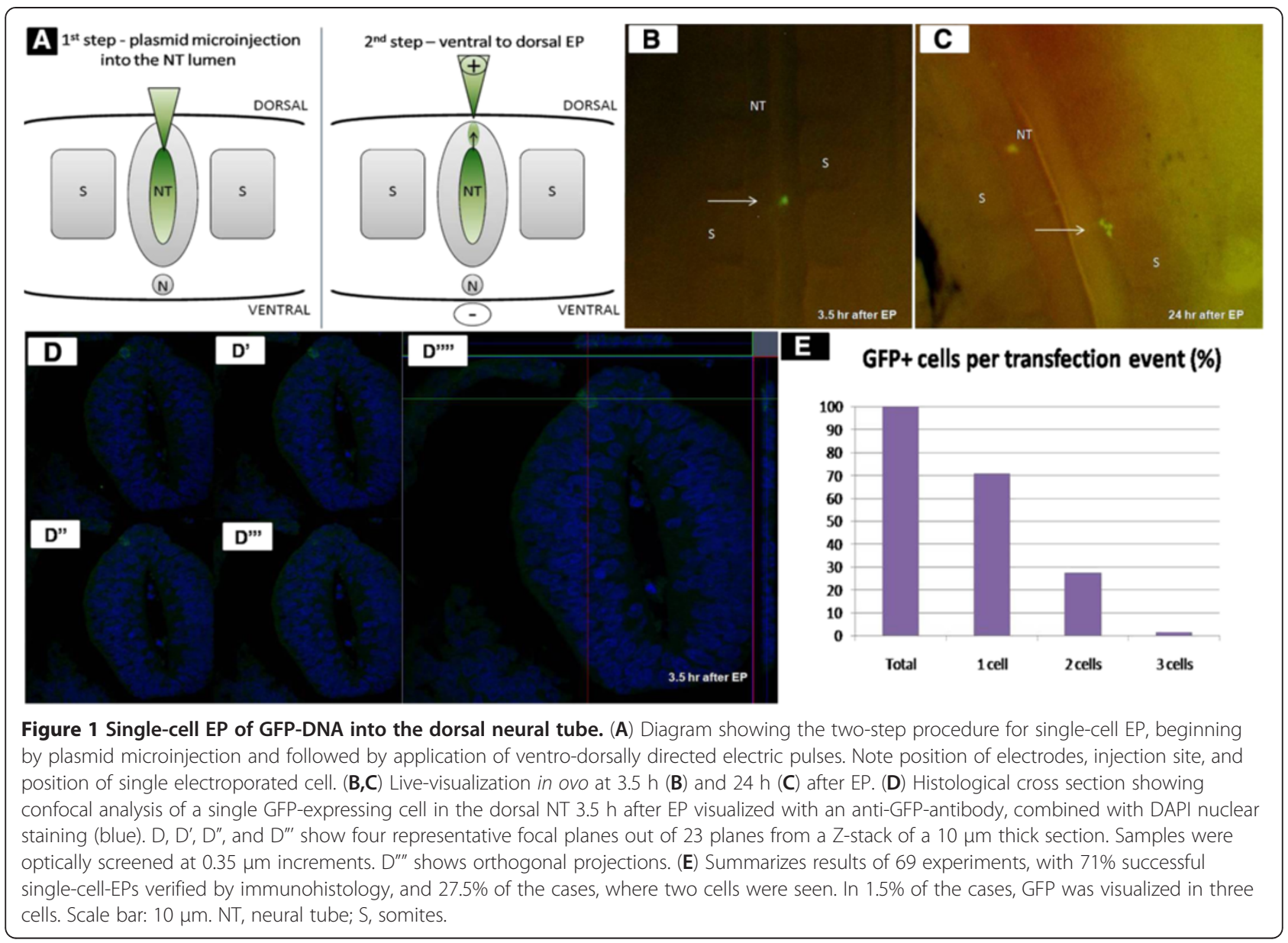

25\% chromaffin-like cells [31]. Likewise, mammalian and avian adrenal glands contain a small proportion of neurons, in addition to the chromaffin cells [32,33]. Thus, the localization of a $\mathrm{TH}+$ cell in sympathetic ganglia and adrenal glands, respectively, does not allow to unequivocally identify it as a neuron or chromaffin cell, respectively. However, in the chick embryo NF-M expression is indicative of a neuronal phenotype [28,34]. We therefore performed $N F-M$ in situ hybridization in combination with GFP- and TH-immunostaining to verify neuronal and neuroendocrine chromaffin phenotypes in the respective locations. Figure $3 \mathrm{~A}-\mathrm{C}$ shows a $\mathrm{GFP}+/ \mathrm{TH}+1$ $\mathrm{NF}-\mathrm{M}+$ cell in a chick sympathetic ganglion at E6, confirming this cell as a neuron; Figure 3D-F reveals two $\mathrm{GFP}+/ \mathrm{TH}+/ N F-M$ - cells in an E6 adrenal gland indicating that these are chromaffin cells. All labelled cells shown in Figure 3 are derivatives of the same clone. In total, 6 single-cell electroporated embryos (out of 24 embryos with derivatives detected in both sympathetic ganglia and adrenal gland) were analysed for GFP and TH immunoreactivities, and NF-M mRNA expression. Figure 3G shows that only one sympathetic ganglion contained, in addition to neurons, a GFP+/TH+/NF-M-negative, presumptive chromaffin-like cell, while three out of six analysed adrenal glands harboured neurons in addition to chromaffin cells. Hence, most cells (1-6) in sympathetic ganglia are $N F$-positive $(P<0.001)$ and most cells $(1-5)$ in adrenal glands are $N F$-negative $(P=0.0017)$.

Altogether, our data suggest that a single $\mathrm{NC}$ progenitor residing in the NT before delamination gives rise to both chromaffin cells and sympathetic neurons. Our findings therefore strongly support the notion that sympathetic neurons and chromaffin cells still share a common progenitor in the dorsal NT prior to delamination.

Consistent with this result, additional NC-derived sublineages are likely to be segregated only after emigration. For example, neurons and glia of sensory ganglia become segregated within the DRG themselves by Notch-dependent lateral inhibition [35]. A similar mechanism might account for segregation of SA progenitors as members of the Delta/Notch family are expressed in subsets of ventrally migrating SA cells [6].

Although growing evidence suggests that fate restrictions in the NC may occur prior to cell emigration [7,29,36-38], this notion should be systematically examined for specific derivatives by single cell lineage analysis in vivo at the 


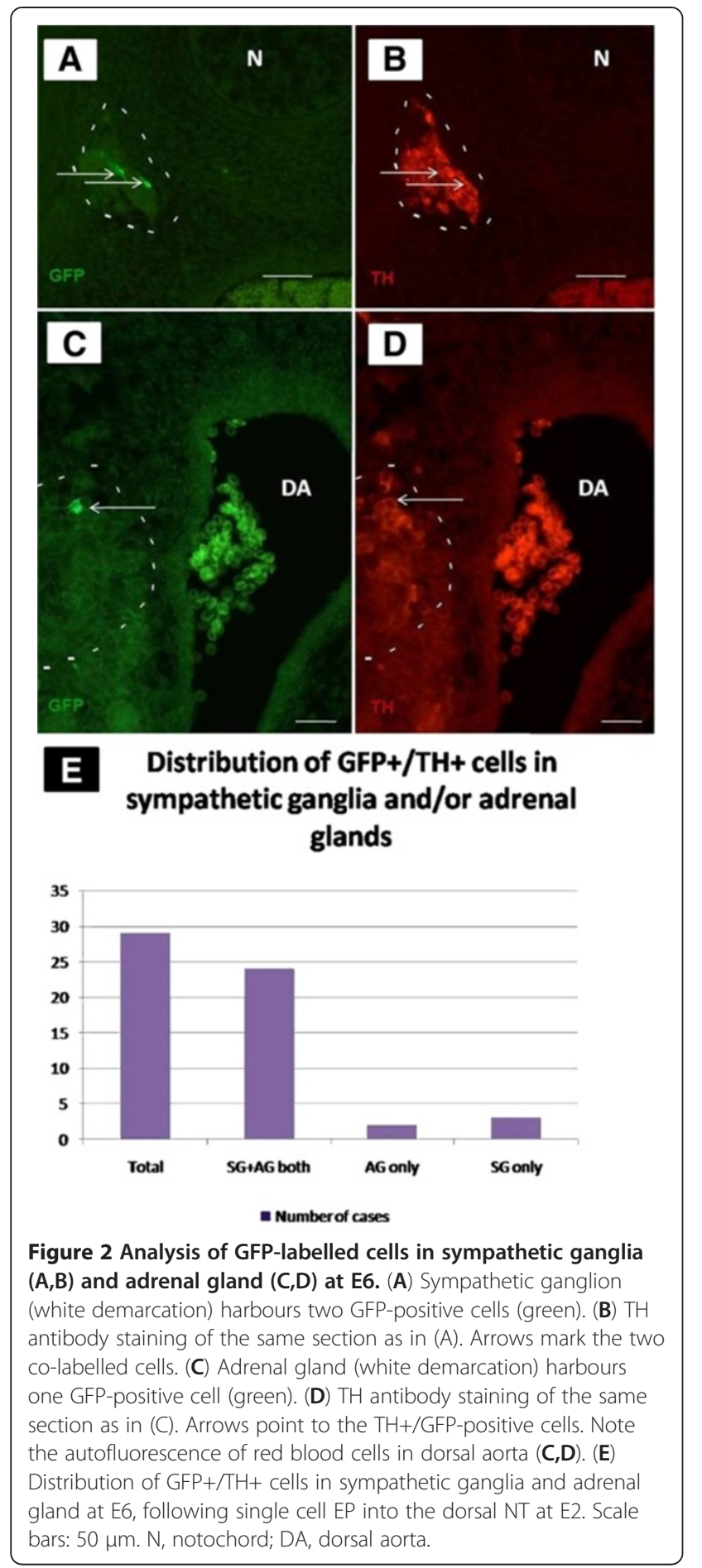

appropriate time and axial location. In our study, this was done by performing single cell EP into the dorsal NT at the time and axial levels from which adrenal chromaffin and sympathetic neuronal progenitors delaminate. Single cell EP is an established method that allows the labelling of an individual cell in the midline of the NT before delamination. Although in ovo single cell EP is a
Table 1 Number of GFP+ cells per clone in the various derivatives

\begin{tabular}{|c|c|c|}
\hline Embryo/Case ID & SG & $A G$ \\
\hline$\# 1$ & 3 & 4 \\
\hline$\# 2$ & 3 & 3 \\
\hline \# 3 & 6 & 6 \\
\hline \# 4 & 5 & 5 \\
\hline \# 5 & 2 & 2 \\
\hline \# 6 & 2 & 3 \\
\hline$\# 7$ & 7 & 3 \\
\hline \# 8 & 6 & 2 \\
\hline$\# 9$ & 5 & 6 \\
\hline \# 10 & 7 & 2 \\
\hline \# 11 & 2 & 3 \\
\hline \# 12 & 10 & 12 \\
\hline \# 13 & 3 & 3 \\
\hline \# 14 & 2 & 3 \\
\hline \# 15 & 11 & 10 \\
\hline \# 16 & 6 & 3 \\
\hline \# 17 & 4 & 3 \\
\hline \# 18 & 3 & 2 \\
\hline \# 19 & 5 & 5 \\
\hline \# 20 & 1 & 3 \\
\hline \# 21 & 5 & 5 \\
\hline \# 22 & 18 & 10 \\
\hline \# 23 & 6 & 5 \\
\hline \# 24 & 4 & 10 \\
\hline \# 25 & 6 & 0 \\
\hline \# 26 & 8 & 0 \\
\hline \# 27 & 6 & 0 \\
\hline \# 28 & 0 & 4 \\
\hline \# 29 & 0 & 5 \\
\hline
\end{tabular}

Results represent the number of GFP+/TH+ cells per clone present in sympathetic ganglia (SG), adrenal gland (AG), or in both tissues counted in a total of 29 labelled clones.

technically demanding technique, with a success rate in our experiments of only $12 \%$, we preferred EP over all other available methods, since it lacks the potential physical damage to the embryo produced by biolistic gene gun, potential toxic effects of viruses [39], and does not harm the morphology of the tissue [40]. Notably, in our experiment, a clear GFP signal was already visible $3.5 \mathrm{~h}$ after EP, likely before most labelled cells underwent mitosis. Consistently, in $71 \%$ of cases, only one cell in the dorsal NT was detected, while $27.5 \%$ of cases revealed two cells. In the latter case, either two cells were originally electroporated, or a single cell was labelled shortly before undergoing cell division. 


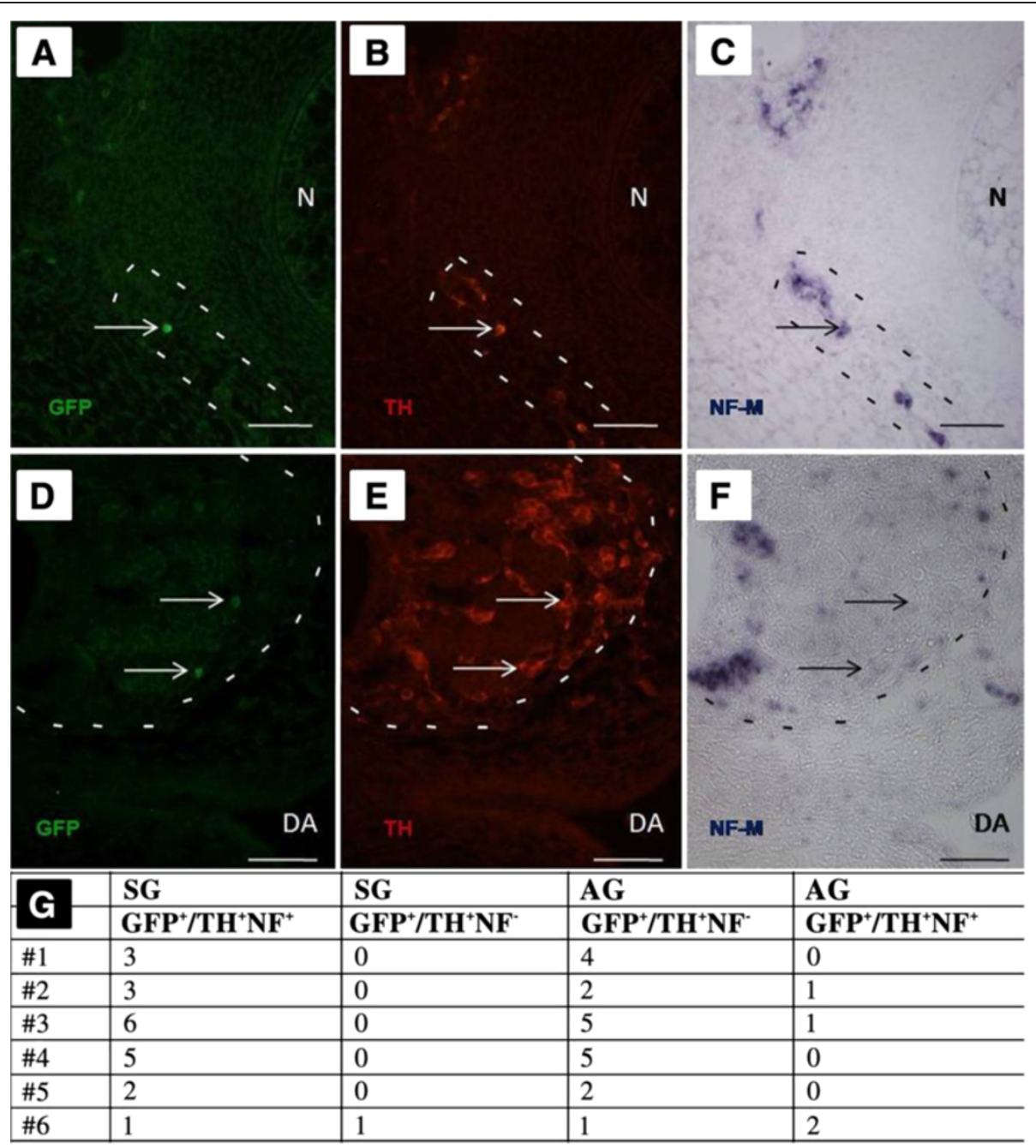

Figure 3 Analysis of GFP-labelled cells derived from a single clone in a sympathetic ganglion (A-C) and adrenal gland (D-F) at E6 using antibodies to GFP $(\mathbf{A}, \mathbf{D})$, TH $(\mathrm{B}, \mathrm{E})$, and in situ hybridization for $\mathbf{N F - M} \mathrm{mRNA}(\mathbf{C}, \mathrm{F})$. (G) Distribution of GFP+/TH+/NF+ and GFP+/TH+/NF- cells in sympathetic ganglia (SG) and adrenal gland (AG) at E6. Scale bars: $50 \mu \mathrm{m}$. N, notochord: DA, dorsal aorta.

\section{Conclusions}

Taken together, our results suggest that sympathetic neuronal and chromaffin NC precursors are not pre-specified at the NT level favouring the option that specification may occur after delamination. Since neuronal and chromaffin progenitors can already be distinguished in their locations prior to populating the final target sites, sympathetic ganglia and adrenal gland, respectively, specification must occur during migration from the NT to the dorsal aorta or early in the peri-aortic area. Underlying mechanisms need to be investigated.

\section{Methods}

\section{Embryos}

Fertilized white Leghorn chicken (Gallus gallus) eggs were from commercial sources (Haas, France). Embryos were staged according to Hamburger and Hamilton [41].

\section{In ovo manipulations}

An expression construct encoding an enhanced version of GFP, the pCAGGS-AFP $(5 \mu \mathrm{g} / \mu \mathrm{L}) \quad[42,43]$ was microinjected into the NT at the level of somites 18-24 of 18-24 somite-stage embryos (HH13). Care was taken to label cells opposite recently segmented epithelial somites as the dorsal midline area of the NT at this stage harbours progenitors that mostly generate sympathetic cells $[7,29]$. For focal EP of dorsal NT cells, a tungsten L-shape negative electrode was placed underneath the blastoderm. The positively charged electrode with the DNA-filled micropipette was inserted into the lumen of the NT. DNA at a concentration of $5 \mu \mathrm{g} / \mu \mathrm{L}$ was injected into the lumen and the micropipette was lifted up, until the tip of the micropipette touched the NT (Figure 1A, $[7,29])$. Immediately after injection four electrical pulses of current at a voltage of $60 \mathrm{~V}$ for $15 \mathrm{~ms}$ were applied at 
$100 \mathrm{~ms}$ intervals using an $\mathrm{ECM}^{\circ} 830$ electroporator (BTX Harvard Apparatus). Single cell labelling was achieved when the resistance of the glass micropipette was 1.8-2.2 $\mathrm{M} \Omega$ (measured after the pulse) using a Multimeter (Alcron). Embryos were re-incubated for $3.5 \mathrm{~h}$ to monitor initial expression of GFP by inspection under a stereomicroscope with fluorescent attachment (Zeiss). Eggs were then re-incubated for an additional 20-24 h after EP to confirm that the cell had delaminated from the NT. Successfully electroporated embryos were then re-incubated until E6.

\section{Embryo processing and sectioning}

Embryos were fixed in $4 \%$ formaldehyde overnight, washed twice in PBS, subsequently dehydrated in ascending concentrations of ethanol and acetone, and embedded in paraffin (Leica Biosystems). Paraffin blocks were cut into 10 $\mu \mathrm{m}$ thin sections on a microtome (Leica), and sections were mounted on Superfrost slides (Langenbrinck). Paraffin sections were deparaffinized and rehydrated before further processing.

\section{Immunohistochemistry and in situ hybridization}

Deparaffinized sections were immunolabelled with antibodies for GFP and TH combined with in situ hybridization for NF-M. A non-radioactive in situ hybridization for chick-specific neurofilament-M (NF-M) was performed [44]. The riboprobes were diluted 1:10 in Tris/EDTA-buffer. Detection was performed with an anti-DIG antibody coupled to alkaline phosphatase and 4-nitroblue tetrazolium chloride/5-bromo-4-chloro-3indolyl-phosphate (NBT/BCIP; Roche). Then, sections were processed for double-immunostaining with antibodies against $\mathrm{TH}$ and GFP. Before applying the primary antibody, antigen retrieval was performed to uncover the epitope of the $\mathrm{TH}$ antigen. Then, sections were incubated in blocking solution (0.5\% Triton-100, $2 \%$ BSA, $1 \mathrm{x}$ PBS) for $1 \mathrm{~h}$. Next, they were incubated over night at $4^{\circ} \mathrm{C}$ with the primary antibodies to GFP (dilution 1:200; Molecular Probes-Invitrogen), and TH (dilution 1:400; Chemicon - Milipore). Secondary antibodies were: $\mathrm{Cy}^{\mathrm{TM}}-568$ goat anti-mouse (IgG) for detection of $\mathrm{TH}$ (dilution 1:400; Invitrogen). For visualization of GFP secondary Biotin-SP-conjugated Donkey anti-rabbit (IgG) antibody (dilution 1:100; Jackson ImmunoResearch) was applied for $1 \mathrm{~h}$, then sections were washed with PBS. After washing, $\mathrm{Cy} 2^{\mathrm{TM}}$-conjugated streptavidine (dilution 1:200, Jackson ImmunoResearch) was applied for $1 \mathrm{~h}$. Nuclei were counterstained with 4,6'-diamidino-2-phenylindole dichloride (DAPI) (dilution $1: 10,000$ in 1xPBS, Boehringer). Sections were incubated for $5 \mathrm{~min}$ with DAPI, then washed in $1 \times \mathrm{PBS}$ and mounted with fluorescent-covering medium Fluoromount-G (Southern Biotech).

\section{Data analysis and statistics}

The in ovo-images were taken with a Zeiss camera equipped with the AxioVision programme, and images were saved in JPG or TIFF format. If necessary, brightness and contrast were adjusted to the entire image using AxioVision and Photoshop 5.0 (AdobeSystems, USA), merged images were prepared using GIMP 2.0. Analysis of paraffin sections was performed using a Zeiss Axiophot microscope. Confocal scanning was performed on 11 embryos, including Z-stacks and orthogonal projections. A Zeiss confocal microscope with a $364 \mathrm{~nm}$ laser, ZEN 2010 software and x63 objective $(1.2 \mathrm{~W})$ was used. Within the NT, a single GFP-labelled cell was apparent in one transverse section.

To evaluate a common progenitor for chromaffin cells and sympathetic neurons, as well as neuronal (NF-M-positive) or neuroendocrine (NF-M-negative) cells, the $x^{2}$ test was used. Analysis of cell numbers in sympathetic ganglia $v s$. adrenal gland was performed using the $t$-test $(P=0.5)$.

\section{Abbreviations \\ AG: Adrenal gland; DAPI: 4',6'-diamidino-2-phenylindole dichloride; E: Embryonic day; EP: Electroporation; GFP: Green fluorescent protein; $\mathrm{HH}$ : Hamburger/Hamilton; ISH: In-situ-hybridization; NC: Neural crest; NF: Neurofilament; NT: Neural tube; PBS: Phosphate-buffered saline; SA: Sympathoadrenal; SG: Sympathetic ganglion; TH: Tyrosine hydroxylase.}

\section{Competing interests}

The authors declare that they have no competing interests.

\section{Authors' contributions}

SS and MS participated in the design, the execution, and/or analysis of the majority of experiments. $\mathrm{KH}$ and SK helped with the interpretation of data and in situ hybridizations. CK and KU designed the study, interpreted the results, and wrote the manuscript with the help of SS. All authors read and approved the final version of the manuscript.

\section{Authors' information}

Chaya Kalcheim and Klaus Unsicker are joint senior authors.

\section{Acknowledgements}

We thank Ute Bauer, Günter Frank, Helmut Gerlach, Lidia Koschny, Ulla Hinz, and Ute Lausch for excellent technical assistance. We thank Dr Angela Naumann, Center for Biological Systems Analysis, for help with confocal microscopy. This work was supported by grants from Deutsche Forschungsgemeinschaft to K Unsicker and C Kalcheim (SFB 488 A6, and SFB 592 A23).

\section{Author details}

${ }^{1}$ Department of Molecular Embryology, Institute of Anatomy and Cell Biology University of Freiburg, Albertstr. 17, Freiburg D-79104, Germany. ${ }^{2}$ Clinical Cooperation Unit Pediatric Oncology, German Cancer Research Center (DKFZ), Heidelberg D-69120, Germany. ${ }^{3}$ Department of Medical Neurobiology, IMRIC and ELSC-Hebrew University of Jerusalem, Hadassah Medical School, POB 12272, Jerusalem 9112102, Israel.

Received: 17 December 2012 Accepted: 17 May 2013

Published: 18 June 2013

\section{References}

1. LeDouarin NM, Kalcheim C: The Neural Crest. Cambridge: Cambridge University Press; 1999.

2. Huber K, Kalcheim C, Unsicker K: The development of the chromaffin cell lineage from the neural crest. Auton Neurosci 2009, 151(1):10-16. 
3. Langley K, Grant NJ: Molecular markers of sympathoadrenal cells. Cell Tissue Res 1999, 298(2):185-206.

4. Unsicker K: The chromaffin cell: paradigm in cell, developmental and growth factor biology. J Anat 1993, 183(Pt 2):207-221.

5. Unsicker K, Huber K, Schütz G, Kalcheim C: The chromaffin cell and its development. Neurochem Res 2005, 30(6-7):921-925.

6. Unsicker K, Huber K, Schober A, Kalcheim C: Resolved and open issues in chromaffin cell development. Mech Dev 2013, 130:324-329.

7. Krispin S, Nitzan E, Kalcheim C: The dorsal neural tube: a dynamic setting for cell fate decisions. Dev Neurobiol 2010, 70(12):796-812.

8. Serbedzija GN, Bronner-Fraser M, Fraser SE: A vital dye analysis of the timing and pathways of avian trunk neural crest cell migration. Development 1989, 106(4):809-816.

9. Reissmann E, Ernsberger U, Francis-West PH, Rueger D, Brickell PM, Rohrer $\mathrm{H}$ : Involvement of bone morphogenetic protein-4 and bone morphogenetic protein-7 in the differentiation of the adrenergic phenotype in developing sympathetic neurons. Development 1996, 122(7):2079-2088.

10. Schneider $\mathrm{C}$, Wicht $\mathrm{H}$, Enderich J, Wegner M, Rohrer $\mathrm{H}$ : Bone morphogenetic proteins are required in vivo for the generation of sympathetic neurons. Neuron 1999, 24(4):861-870.

11. Ernsberger U, Patzke H, Tissier-Seta J-P, Reh T, Goridis C, Rohrer H: The expression of tyrosine hydroxylase and the transcription factors CPhox-2 and Cash-1: evidence for distinct inductive steps in the differentiation of chick sympathetic precursor cells. Mech Dev 1995, 52(1):125-136.

12. Guillemot F, Lo LC, Johnson JE, Auerbach A, Anderson DJ, Joyner AL: Mammalian achaete-scute homolog 1 is required for the early development of olfactory and autonomic neurons. Cell 1993, 75(3):463-476.

13. Ernsberger $\mathrm{U}$, Reissmann E, Mason I, Rohrer H: The expression of dopamine beta-hydroxylase, tyrosine hydroxylase, and Phox2 transcription factors in sympathetic neurons: evidence for common regulation during noradrenergic induction and diverging regulation later in development. Mech Dev 2000, 92(2):169-177.

14. Howard MJ, Stanke M, Schneider C, Wu X, Rohrer H: The transcription factor dHAND is a downstream effector of BMPs in sympathetic neuron specification. Development 2000, 127(18):4073-4081.

15. Lucas ME, Muller F, Rudiger R, Henion PD, Rohrer $\mathrm{H}$ : The bHLH transcription factor hand 2 is essential for noradrenergic differentiation of sympathetic neurons. Development 2006, 133:4015-4024.

16. Pattyn A, Morin X, Cremer H, Goridis C, Brunet JF: Expression and interactions of the two closely related homeobox genes Phox2a and Phox2b during neurogenesis. Development 1997, 124:4065-4075.

17. Pattyn A, Morin X, Cremer H, Goridis C, Brunet JF: The homeobox gene Phox $2 b$ is essential for the development of autonomic neural crest derivatives. Nature 1999, 399:366-370.

18. Tsarovina K, Pattyn A, Stubbusch J, Müller F, Wees J, Schneider C, Brunet JF: Essential role of Gata transcription factors in sympathetic neuron development. Development 2004, 131(19):4775-4786.

19. Wildner H, Gierl MS, Strehle M, Pla P, Birchmeier C: Insm1 (IA-1) is a crucial component of the transcriptional network that controls differentiation of the sympatho-adrenal lineage. Development 2008, 135(3):473-481.

20. Huber K: The sympathoadrenal cell lineage: specification, diversification, and new perspectives. Dev Biol 2006, 298(2):335-343.

21. Rohrer $\mathrm{H}$ : Transcriptional control of differentiation and neurogenesis in autonomic ganglia. Eur J Neurosci 2011, 34(10):1563-1573.

22. Anderson DJ, Axel R: A bipotential neuroendocrine precursor whose choice of cell fate is determined by NGF and glucocorticoids. Cell 1986, 47(6):1079-1090.

23. Michelsohn AM, Anderson DJ: Changes in competence determine the timing of two sequential glucocorticoid effects on sympathoadrenal progenitors. Neuron 1992, 8(3):589-604.

24. Unsicker K, Krisch B, Otten U, Thoenen H: Nerve growth factor-induced fiber outgrowth from isolated rat adrenal chromaffin cells: impairment by glucocorticoids. Proc Natl Acad Sci U S A 1978, 75(7):3498-3502.

25. Anderson DJ: Cell fate determination in the peripheral nervous system: the sympathoadrenal progenitor. J Neurobio/ 1993, 24(2):185-198.

26. Finotto S, Krieglstein K, Schober A, Deimling F, Lindner K, Brühl B, Beier K, Metz J, Garcia-Arraras JE, Roig-Lopez JL, Monaghan P, Schmid W, Cole TJ, Kellendonk C, Tronche F, Schütz G, Unsicker K: Analysis of mice carrying targeted mutations of the glucocorticoid receptor gene argues against an essential role of glucocorticoid signalling for generating adrenal chromaffin cells. Development 1999, 126(13):2935-2944.
27. Gut P, Huber K, Lohr J, Brühl B, Oberle S, Treier M, Ernsberger U, Kalcheim C, Unsicker K: Lack of an adrenal cortex in Sf1 mutant mice is compatible with the generation and differentiation of chromaffin cells. Development 2005, 132(20):4611-4619.

28. Ernsberger U, Esposito L, Partimo S, Huber K, Franke A, Bixby JL, Kalcheim C, Unsicker K: Expression of neuronal markers suggests heterogeneity of chick sympathoadrenal cells prior to invasion of the adrenal anlagen. Cell Tissue Res 2005, 319(1):1-13.

29. Krispin S, Nitzan E, Kassem Y, Kalcheim C: Evidence for a dynamic spatiotemporal fate map and early fate restrictions of premigratory avian neural crest. Development 2010, 137:585-595.

30. LeDouarin NM, Creuzet S, Couly G, Dupin E: Neural crest cell plasticity and its limits. Development 2004, 131(19):4637-4650.

31. Huber K, Franke A, Brühl B, Krispin S, Ernsberger U, Schober A, Von Bohlen Und Halbach O, Rohrer $\mathrm{H}$, Kalcheim C, Unsicker K: Persistent expression of BMP-4 in embryonic chick adrenal cortical cells and its role in chromaffin cell development. Neural Dev 2008, 3:28.

32. Unsicker K: Fine structure and innervation of the avian adrenal gland. I Fine structure of adrenal chromaffin cells and ganglion cells. Z Zellforsch Mikrosk Anat 1973, 145:389-416.

33. Unsicker K, Habura-Flüh O, Zwarg J: Different types of small granule containing cells and neurons in the guinea pig adrenal medulla. Cell Tissue Res 1978, 189(1):109-130.

34. Vogel KS, Weston JA: The sympathoadrenal lineage in avian embryos. I. Adrenal chromaffin cells lose neuronal traits during embryogenesis. Dev Biol 1990, 139(1):1-12.

35. Wakamatsu Y, Maynard TM, Weston JA: Fate determination of neural crest cells by NOTCH-mediated lateral inhibition and asymmetrical cell division during gangliogenesis. Development 2000, 127(13):2811-2821.

36. Anderson DJ: Genes, lineages and the neural crest: a speculative review. Philos Trans R Soc Lond B Biol SC 2000, 355(1399):953-964.

37. Dorsky Rl, Moon RT, Raible DW: Environmental signals and cell fate specification in premigratory neural crest. Bioessays 2000, 22(8):708-716.

38. Harris ML, Erickson CA: Lineage specification in neural crest cell path finding. Dev Dyn 2007, 236(1):1-19.

39. Hass K, Sin WC, Javaherian A, Li Z, Cline HT: Single-cell electroporation for gene transfer in vivo. Neuron 2001, 29:583-591.

40. Brown CY, Eom DS, Amarnath S, Agarwala S: A simple technique for early in vivo electroporation of E1 chick embryos. Dev Dyn 2012, 241(3):545-552.

41. Hamburger $V$, Hamilton HL: A series of normal stages in the development of the chick embryo 1951. Dev Dyn 1992, 195(4):231-272.

42. Ben-Yair R, Kalcheim C: Lineage analysis of the avian dermomyotome sheet reveals the existence of single cells with both dermal and muscle progenitor fates. Development 2005, 132(4):689-701.

43. Momose T, Tonegawa A, Takeuchi J, Ogawa H, Umesono K, Yasuda K: Efficient targeting of gene expression in chick embryos by microelectroporation. Dev Growth Differ 1999, 41:335-344.

44. Zopf D, Hermans-Borgmeyer I, Gundelfinger ED, Betz H: Identification of gene products expressed in the developing chick visual system: characterization of a middle-molecular-weight neurofilament cDNA. Genes Dev 1987, 1(7):699-708.

\section{doi:10.1186/1749-8104-8-12}

Cite this article as: Shtukmaster et al: Sympathetic neurons and chromaffin cells share a common progenitor in the neural crest in vivo. Neural Development 2013 8:12. 